\title{
The pneumococcal response to oxidative stress includes a role for Rgg
}

\begin{abstract}
Correspondence
Hasan Yesilkaya

hy3@le.ac.uk
\end{abstract}

Received 16 February 2009

Revised 10 September 2009

Accepted 11 September 2009

\author{
Magda E. Bortoni, ${ }^{1,2}$ Vanessa S. Terra, ${ }^{1}$ Jason Hinds, ${ }^{3}$ Peter W. Andrew ${ }^{1}$ \\ and Hasan Yesilkaya ${ }^{1}$ \\ ${ }^{1}$ Department of Infection, Immunity and Inflammation, University of Leicester, Leicester \\ LE1 9HN, UK \\ ${ }^{2}$ Department of Basic Sciences, Universidad De Monterrey, Monterrey 66238, Mexico \\ ${ }^{3}$ Division of Cellular and Molecular Medicine, St George's Hospital Medical School, University of \\ London, London SW17 ORE, UK
}

\begin{abstract}
Streptococcus pneumoniae resides in the oxygen-rich environment of the upper respiratory tract, and therefore the ability to survive in the presence of oxygen is an important aspect of its in vivo survival. To investigate how $S$. pneumoniae adapts to oxygen, we determined the global gene expression profile of the micro-organism in aerobiosis and anaerobiosis. It was found that exposure to aerobiosis elevated the expression of 54 genes, while the expression of 15 genes was downregulated. Notably there were significant changes in putative genome plasticity and hypothetical genes. In addition, increased expression of rgg, a putative transcriptional regulator, was detected. To test the role of Rgg in the pneumococcal oxidative stress response, an isogenic mutant was constructed. It was found that the mutant was sensitive to oxygen and paraquat, but not to $\mathrm{H}_{2} \mathrm{O}_{2}$. In addition, the absence of Rgg strongly reduced the biofilm-forming ability of an unencapsulated pneumococcus. Virulence studies showed that the median survival time of mice infected intranasally with the rgg mutant was significantly longer than that of the wild-typeinfected group, and the animals infected with the mutant developed septicaemia later than those infected intranasally with the wild-type.
\end{abstract}

\section{INTRODUCTION}

Streptococcus pneumoniae is an aerotolerant Gram-positive bacterium that causes an array of diseases, including pneumonia, otitis media and meningitis (Kadioglu et al., 2008). The ability to cause diseases in diverse in vivo environments suggests that the micro-organism is equipped with robust mechanisms to sense and adapt to changing environmental parameters, such as variation in the concentration of oxygen. Indeed, the importance of proteins involved in the oxidative stress response for pneumococcal biology has been demonstrated in various studies (Auzat et al., 1999; Giuliodori et al., 2007; McDougald et al., 2002; Yesilkaya et al., 2000).

Bacteria employ mainly enzymic mechanisms to eliminate the damaging effects of oxidative stress, such as superoxide dismutase (Auzat et al., 1999; Giuliodori et al., 2007; McDougald et al., 2002; Yesilkaya et al., 2000), NADH

Abbreviations: ABC, ATP binding cassette; PTS, phosphotransferase system; qRT-PCR, quantitative RT-PCR; ROS, reactive oxygen species.

Fully annotated microarray data have been deposited in B $\mu \mathrm{G} @$ Sbase (accession number E-BUGS-70; http://bugs.sgul.ac.uk/E-BUGS-70) and also ArrayExpress (accession number E-BUGS-70). oxidase (Auzat et al., 1999; Giuliodori et al., 2007; McDougald et al., 2002; Yesilkaya et al., 2000), catalase (Rocha et al., 1996), glutathione peroxidase, glutathione reductase (Vergauwen et al., 2003), thiol peroxidase (Cha et al., 2004) and alkyl hydroperoxidase (Paterson et al., 2006). The presence of one or several of these enzymes has been shown in many pathogenic bacteria, and they have been linked to microbial virulence (Cha et al., 2004; Cianciotto, 2001; Yesilkaya et al., 2000).

The pneumococcus has to deal with changing concentrations of oxygen during infection. Although some aspects of the pneumococcal response to oxidative stress have been described, information generally is fragmentary. The presence of pneumococcal superoxide dismutase (Yesilkaya et al., 2000), NADH oxidase (Auzat et al., 1999) and alkyl hydroperoxidase (Paterson et al., 2006) has been shown, and their importance in the pneumococcal oxidative stress response has been established (Auzat et al., 1999; Spellerberg et al., 1996). Previously, we have shown that $S$. pneumoniae synthesizes a manganese-dependent superoxide dismutase, SodA. A $\operatorname{sodA}$ pneumococcal mutant is more susceptible to the oxidative stress induced by paraquat and less virulent in a mouse model of pneumonia (Yesilkaya et al., 2000). Additionally, some of 
the pneumococcal surface antigens have also been linked to oxidative stress response, such as pneumococcal surface antigen $\mathrm{A}$, inactivation of which renders pneumococci susceptible to $\mathrm{H}_{2} \mathrm{O}_{2}$ (Tseng et al., 2002; McCluskey et al., 2004).

In silico analysis of the pneumococcal genome revealed other genes whose products have been implicated in oxidative defence in other bacteria. However, their role in the pneumococcal oxidative response remains to be investigated. These genes include tpX (thiol peroxidase), SP0313 (glutathione peroxidase), $n$th (endonuclease III), and genes encoding several heat-shock proteins, such as groEL, groES and dnaK (Tettelin et al., 2002). Significantly though, the pneumococcus has neither catalase nor oxidative stress response regulators that are present in other microorganisms, for instance oxyR, soxRS and perR (Tettelin et al., 2002). Hence, the first aim of this work was to study the global oxidative stress response of $S$. pneumoniae.

Noteworthy within the pneumococcal oxidative stress response was $r g g$ overexpression. This putative transcriptional regulator is present in several other Gram-positive bacteria, and has been shown to be involved in regulation of glutamate-dependent acid tolerance, the synthesis of glucosyltransferase, utilization of non-glucose carbohydrates, prophage induction and oxidative stress (Chaussee et al., 2003, 2004; Kreikemeyer et al., 2003; Pulliainen et al., 2008). However, there is no report on the contribution of Rgg to pneumococcal biology. Hence the second aim of this work was to define a role for Rgg in the pneumococcus. For this, we constructed an isogenic mutant strain and tested its response to oxidative stress, biofilm formation and virulence.

\section{METHODS}

Bacterial strains and growth conditions. S. pneumoniae type 2 strain D39 and its unencapsulated derivative R6 were used in this study. Routinely, $S$. pneumoniae strains were grown in brain heart infusion (BHI) broth or tryptic soy broth (TSB), or on blood agar plates supplemented with $5 \%(\mathrm{v} / \mathrm{v})$ defibrinated horse blood, at $37{ }^{\circ} \mathrm{C}$. Sicard's defined medium (Sicard, 1964) was used for oxygen, paraquat and $\mathrm{H}_{2} \mathrm{O}_{2}$ susceptibility assays in order to eliminate the scavengers of reactive oxygen species (ROS) that may be found in rich medium. Where appropriate, spectinomycin $\left(100 \mu \mathrm{g} \mathrm{ml}^{-1}\right)$ was added to the culture medium.

For micro-aerobic growth, tightly closed culture tubes were used. Anaerobic growth conditions were created by using GasPak Anaerobic System Envelopes (BD BBL) in a jar containing a platinum catalyst, and anaerobiosis was monitored with an anaerobic indicator (BD BBL Dry Anaerobic Indicator Strips). With this method, at the time of inoculation, there was $10 \%(\mathrm{v} / \mathrm{v})$ dissolved oxygen, which decreased to $2 \%(\mathrm{v} / \mathrm{v})$ by $2 \mathrm{~h}$ and to $0 \%$ by the time the bacteria reached mid-exponential phase at $\sim 4 \mathrm{~h}\left(\mathrm{OD}_{500} \sim 0.6\right)$.

For aerobic growth, culture flasks were placed in a water bath at $37{ }^{\circ} \mathrm{C}$ with a stream of filtered air bubbled through the culture. The oxygen concentration remained at $20 \%(\mathrm{v} / \mathrm{v})$ until mid-exponential phase $\left(\mathrm{OD}_{500} \sim 0.6\right)$, then the concentration dropped to $\sim 10 \%$ by stationary phase $\left(\mathrm{OD}_{500} \sim 1.3\right)$.
Biofilm formation assay. The biofilm formation assay was done in flat-bottomed polystyrene tissue-culture plates (96-well plates; Sarstedt) as described previously (Oggioni et al., 2006). Frozen pneumococcal cultures (about $1 \times 10^{8}$ c.f.u. $\mathrm{ml}^{-1}$ ) were diluted $1: 100$ in $200 \mu \mathrm{l} \mathrm{TSB}$ and $100 \mathrm{ng} \mathrm{ml}^{-1}$ competence-stimulating peptide (Inbios). After incubation at $37^{\circ} \mathrm{C}$ for $18-24 \mathrm{~h}$, the supernatant was decanted and wells were washed four times with $200 \mu$ ice-cold TSB to remove planktonic cells. Then, $100 \mu \mathrm{l}$ TSB containing $10 \%(\mathrm{v} / \mathrm{v})$ glycerol was added and the biofilm was detached by $2 \mathrm{~s}$ sonication in a sonicating water bath. The biofilm-forming cells were quantified by plating on blood agar.

$\mathbf{H}_{\mathbf{2}} \mathbf{O}_{\mathbf{2}}$ survival assay. Mid-exponential phase cultures $(50 \mu \mathrm{l})\left(\mathrm{OD}_{500}\right.$ $\sim 0.6$ ), were centrifuged to remove supernatant and resuspended in an equal volume of PBS ( $\mathrm{pH} 7.0$ ). The bacteria were mixed with $50 \mu \mathrm{l}$ $\mathrm{H}_{2} \mathrm{O}_{2}$ (Sigma) to give a final concentration of 20 or $40 \mathrm{mM} \mathrm{H}_{2} \mathrm{O}_{2}$, and the reaction was incubated at $37^{\circ} \mathrm{C}$ for 5 or $20 \mathrm{~min}$. The control reactions contained bacteria and PBS. c.f.u. were determined by serial dilution and plating on blood agar plates. The results were expressed as percentage survival relative to the control.

Paraquat-susceptibility assay. The pneumococcal inoculum was prepared as described above, and exposed to either 0.05 or $0.1 \mathrm{mM}$ paraquat for 1 h. c.f.u. were determined by serial dilution and plating on blood agar plates. The results were expressed as percentage survival relative to the control.

RNA extraction and purification. The extraction of RNA was done as described previously (Stewart et al., 2002). The pneumococcal cultures were grown in BHI broth under aerobic or anaerobic conditions until mid-exponential phase $\left(\mathrm{OD}_{500} \sim 0.6\right)$, and were immediately mixed with GTC solution [5 M guanidine isothiocyanate, $0.5 \%(\mathrm{w} / \mathrm{v})$ sodium $\mathrm{N}$-lauryl sarcosine, $25 \mathrm{mM}$ trisodium citrate (pH 7.0), $100 \mathrm{mM} 2$-mercaptoethanol and $0.5 \%(\mathrm{v} / \mathrm{v})$ Tween 80$]$. The bacteria were harvested by centrifugation at $5000 \mathrm{~g}$ for $20 \mathrm{~min}$ and the pellet was resuspended in $1.2 \mathrm{ml} \mathrm{RNAzol} \mathrm{(Sigma).} \mathrm{This} \mathrm{was} \mathrm{transferred}$ to a RiboLyser blue matrix tube (Hybaid) and processed in a RiboLyser (Hybaid) at 6.5 power setting for $45 \mathrm{~s}$. The RNA was extracted first with chloroform and then precipitated with 2-propanol. Finally, the RNA was treated with amplification grade DNase I (Invitrogen) before purification with an RNeasy Mini kit (Qiagen).

Microarray experiments. The R6 strain was used for microarray experiments. Microarray slides were obtained from the Bacterial Microarray Group at St. George's Hospital Medical School, University of London. The SPv1.1.0 array consisted of spotted PCR products that represent all of the genes in the S. pneumoniae TIGR4 and R6 genomes. The array design is available in B $\mu \mathrm{G} @$ Sbase (accession number A-BUGS-14; http://bugs.sgul.ac.uk/A-BUGS-14) and also ArrayExpress (accession number A-BUGS-14). The experimental procedures for microarray analysis followed previously reported methodology (Stewart et al., 2002), as briefly described below.

RNA $(2-10 \mu \mathrm{g})$ extracted from strain R6 was labelled with either Cy3 or Cy5 dCTP (Invitrogen) during cDNA synthesis using SuperScript II reverse transcriptase (Invitrogen) and random primers (Invitrogen). Cy3- and Cy5-labelled cDNAs were mixed and purified using a MiniElute Purification kit (Qiagen). Microarray slides were pre-hybridized with freshly prepared pre-warmed pre-hybridization solution of $3.5 \times \operatorname{SSC}(3 \mathrm{M} \mathrm{NaCl}, 300 \mathrm{mM}$ sodium citrate, $\mathrm{pH} 7.0)$ containing $0.1 \%(\mathrm{v} / \mathrm{v})$ SDS and $5 \mathrm{mg} \mathrm{BSA} \mathrm{ml}{ }^{-1}$ for $20 \mathrm{~min}$ at $65{ }^{\circ} \mathrm{C}$. The slides were thoroughly rinsed, first in sterile nano-pure water for $1 \mathrm{~min}$ and then in 2-propanol for a further $1 \mathrm{~min}$. The excess liquid on the slide was removed by centrifugation at $500 \mathrm{~g}$ for $5 \mathrm{~min}$ and hybridized within $1 \mathrm{~h}$.

The hybridization mixture contained purified Cy3/Cy5-labelled cDNA samples in $4 \times$ SSC and $0.3 \%(\mathrm{v} / \mathrm{v})$ SDS in a total volume 
of $23 \mu$ l. This was heated to $95{ }^{\circ} \mathrm{C}$ for $2 \mathrm{~min}$ and left to cool slightly at room temperature. The slide was then incubated at $65{ }^{\circ} \mathrm{C}$ in the dark for $16-20 \mathrm{~h}$ in a hybridization cassette. After this, the slide was washed for 2 min three times, first with $1 \times$ SSC, $0.5 \%(\mathrm{v} / \mathrm{v})$ SDS, and then twice with $0.6 \times$ SSC. Finally, the excess liquid was removed by centrifugation at $500 \mathrm{~g}$ for $5 \mathrm{~min}$.

Analysis of microarrays. The microarray slides were scanned using an Axon GenePix 4000A microarray scanner, which utilizes GenePix 5.1 software (Molecular Devices) for identification and for a visual analysis of the quality of the spots. Each spot was visually assessed as 'good', 'bad' or 'not found'. 'Good' spots could be clearly distinguished from the background, and had an 'average' size. 'Bad' spots were affected by artefacts, such as lines of dye across the array, or were very small or too big, while 'not found' indicated the apparent absence of hybridization. The raw intensity data obtained from five independent experiments were normalized and further analysed using GeneSpring 7.3 software (Agilent Technologies). Data were subjected to LOWESS intensity-dependent normalization. This normalization method is commonly used for two-colour experiments and corrects for dye incorporation artefacts (GeneSpring user manual). Statistically significant changes in gene expression between aerobic and anaerobic samples were determined as $t$-test $P$ values $<0.05$ after Benjamini and Hochberg false discovery rate correction (Green \& Diggle, 2007). Genes of interest were further identified by requiring $>$ twofold differences in all five samples analysed. In addition, the microarray results for selected genes whose expression significantly altered in aerobiosis relative to anaerobiosis, were verified and confirmed by real-time quantitative RT-PCR (qRT-PCR) in order to ensure that dye affinity did not bias the results.

qRT-PCR. Two independent RNA preparations were used for qRTPCR analysis. First-strand cDNA synthesis was performed on approximately $1 \mu \mathrm{g}$ DNase-treated total RNA, immediately after isolation, using $200 \mathrm{U}$ SuperScript II reverse transcriptase (Invitrogen) and random hexamers at $42{ }^{\circ} \mathrm{C}$ for $55 \mathrm{~min}$ (Yesilkaya et al., 2006). cDNA (15 ng) was amplified in a $20 \mu$ reaction volume that contained $1 \times$ SYBR Green PCR master mix (Applied Biosystems) and 3 pmol of each primer (Table 1). The transcription level of specific genes was normalized to gyrB transcription, amplified

Table 1. Primers used in this study

\begin{tabular}{|c|c|}
\hline Primer & Primer sequence $\left(5^{\prime}-3^{\prime}\right)$ \\
\hline \multicolumn{2}{|c|}{ Mutation primers } \\
\hline A-SOE-F & AAGGATCCAAGAGGCATACGCAGGCCAC \\
\hline B-SOE-R & GTATTCACGAACGAAAATCGATCACGACCGAATGTTGAATATCTGC \\
\hline C-SOE-F & GCATAACTTTCTCGTCCATATCGGACTTTTCCAATCTGCTCCATAG \\
\hline D-SOE-R & AAGGATCCAAGTGATTGGCCTGCTTAACGAG \\
\hline MP127 & CCGGGGACTTATCAGCCAACC \\
\hline MP128 & TACTAGCGACGCCATCTATGTG \\
\hline RGGF & AAGAGGCATACGCAGGCCAC \\
\hline RGGR & AAGTGATTGGCCTGCTTAACGAG \\
\hline specSOE-F & GATCGATTTTCGTTCGTGAATAC \\
\hline specSOE-R & CGATATGGACGAGAAAGTTATGC \\
\hline \multicolumn{2}{|c|}{ Primers for gene expression analysis } \\
\hline spr0186F & ACGGGGAAAGTCAGGACACTGG \\
\hline spr0186R & TGGGTACTACCAGATGGCGTCC \\
\hline spr0288F & ACCGCACTCCCTGCCAACGAG \\
\hline spr0288R & ACTTTGACGACAACCAAAGCCGTTC \\
\hline spr0674F & TGGCGGACACTTGAACCACG \\
\hline spr0674R & ACGAGTTGTTGCTGCTGCAGTG \\
\hline spd0674F & ACACCCTGAAATCGGTGAAG \\
\hline spd0674R & AGCTGTTTTCTCGGGAGTCA \\
\hline sp0806F & TCGTGTGGCTGCCAAGCGTG \\
\hline sp0806R & GGCTGATCCACCAGCTGAGTC \\
\hline spr1349F & ACCTGCTTTGAAGACACCTCATGT \\
\hline spr1349R & TCAAGATAGCCCAAGCTTGCTCA \\
\hline $\operatorname{spr} 1367 \mathrm{~F}$ & TGCTGAGGTGGTCAATCAGGCTCT \\
\hline spr1367R & AGTTCCСCTTTCCCAAGAGGCA \\
\hline spr1495F & AGTCGGCGACAAGGCGCTTG \\
\hline spr1495R & CGACGTGTTTGAGTTGAGCAGATGC \\
\hline $\operatorname{spr} 1685 \mathrm{~F}$ & TGCCTTGGTAGGACCTATGGCCT \\
\hline $\operatorname{spr} 1685 \mathrm{R}$ & ATCAAGGCTTGCCCCAAGGT \\
\hline spr1932F & ATGCTTTTGGTGCTTCGATT \\
\hline spr1932R & CTCGTGTAATCTGCCCGAAT \\
\hline spr1933F & TCACTGAGACAAGCAACCGGAGG \\
\hline spr1933R & ACCTCTTGCCAGAAAGAGGATCTCC \\
\hline spr2012F & TCGTTCAGAGCGCTTGGGGACAG \\
\hline spr2012R & ACATCCTTAGCACCAGCTTCTTCC \\
\hline
\end{tabular}


Table 2. Genes identified by microarray that undergo a change of expression when S. pneumoniae R6 is grown under aerobiosis compared with growth anaerobically

The genes are divided into groups according to their predicted products. Genes expressed more in anaerobiosis are indicated with an arrow ( $\downarrow$ ). The annotation was based on the R6 genome (indicated by an 'SPR' prefix) (Hoskins et al., 2001), and genes specific for strain TIGR4 are indicated by an 'SP' prefix (Tettelin et al., 2002).

\begin{tabular}{|c|c|c|c|c|c|}
\hline $\begin{array}{l}\text { Category and } \\
\text { gene ID }\end{array}$ & Gene & Description & Fold change & $P$ value & $\begin{array}{c}\text { qRT-PCR } \\
\text { confirmation }^{*}\end{array}$ \\
\hline \multicolumn{6}{|c|}{ Known oxidative stress-related } \\
\hline SPR0674 & $\operatorname{sod} A$ & Superoxide dismutase & 8 & 0.001 & $3.6(0)$ \\
\hline SPR1495 & $t p x$ & Thiol peroxidase & 12 & 0.003 & $9.4(0.2)$ \\
\hline \multicolumn{6}{|c|}{ Hypothetical and conserved hypothetical } \\
\hline SPR0084 & & Conserved hypothetical protein & 4 & 0.001 & \\
\hline SPR0186 & & Hypothetical protein & $\downarrow 12$ & 0.002 & $0.3(0.09)$ \\
\hline SPR0289 & & Hypothetical protein & $\downarrow 12$ & 0.00007 & \\
\hline SPR0429 & & Conserved hypothetical protein & $\downarrow 7$ & 0.007 & \\
\hline SPR0643 & & Hypothetical protein & 4 & 0.003 & \\
\hline SPR0965 & & Hypothetical protein & 3 & 0.001 & \\
\hline SPR0966 & & Conserved hypothetical protein & 4 & 0.0001 & \\
\hline SPR0967 & & Conserved hypothetical protein & 4 & 0.0001 & \\
\hline SPR0968 & & Hypothetical protein & 15 & 0.00001 & \\
\hline SPR0895 & & Conserved hypothetical protein & 4 & 0.002 & \\
\hline SPR1129 & & Hypothetical protein & 19 & 0.00005 & \\
\hline SP1332 & & Hypothetical protein & 16 & 0.00008 & \\
\hline SP1346 & & Conserved hypothetical protein & 4 & 0.00002 & \\
\hline SPR1280 & & Hypothetical protein & 6 & 0.0000002 & \\
\hline SPR1313 & & Hypothetical protein & 3 & 0.0001 & \\
\hline SPR1348 & & Hypothetical protein & 4 & 0.006 & \\
\hline SPR1535 & & Conserved hypothetical protein & 5 & 0.0007 & \\
\hline SPR1537 & & Hypothetical protein & 2 & 0.001 & \\
\hline SPR1572 & & Hypothetical protein & 3 & 0.0000003 & \\
\hline SPR1623 & & Hypothetical protein & 3 & 0.003 & \\
\hline SP2004 & & Hypothetical protein & 4 & 0.007 & \\
\hline SPR1830 & & Hypothetical protein & 3 & 0.0001 & \\
\hline SPR1857 & & Hypothetical protein & 5 & 0.0002 & \\
\hline SPR1858 & & Hypothetical protein & 6 & 0.00008 & \\
\hline SPR1859 & & Hypothetical protein & 4 & 0.0007 & \\
\hline SPR1914 & & Hypothetical protein & 3 & 0.0008 & \\
\hline SPR1983 & & Conserved hypothetical protein & 6 & 0.001 & \\
\hline \multicolumn{6}{|c|}{ Bgl and PTS-related } \\
\hline SPR1843 & & Transcriptional regulator, BglG family & 9 & 0.002 & \\
\hline SPR1845 & $\operatorname{sga}$ & Hexulose-6-phosphate isomerase & 5 & 0.0008 & \\
\hline SPR1846 & $s g h$ & Hexulose-6-phosphate synthase & 6 & 0.0002 & \\
\hline SPR1847 & PTS-EII & PTS system, IIA component & 6 & 0.01 & \\
\hline SPR1849 & PTS-EII & PTS system, membrane component & 6 & 0.0004 & \\
\hline \multicolumn{6}{|c|}{$\mathrm{ABC}$ transporters } \\
\hline SPR1281 & $A B C-N B D$ & $\mathrm{ABC}$ transporter, multidrug efflux & 4 & 0.001 & \\
\hline SPR1289 & $A B C-N / P$ & $\mathrm{ABC}$ transporter, ATP-binding & 13 & 0.007 & \\
\hline SPR1290 & $A B C-N / P$ & $\mathrm{ABC}$ transporter, ATP-binding & 4 & 0.00006 & \\
\hline SPR1293 & $A B C-N B D$ & $\mathrm{ABC}$ transporter, ATP-binding & 14 & 0.00009 & \\
\hline SPR1294 & & $\mathrm{ABC}$ transporter & 5 & 0.0006 & \\
\hline SPR1684 & fatD & Iron-compound $\mathrm{ABC}$ transporter & $\downarrow 6$ & 0.003 & \\
\hline SPR1685 & fat $C$ & Iron-compound $\mathrm{ABC}$ transporter & $\downarrow 14$ & 0.002 & $0.12(0.01)$ \\
\hline SPR1686 & fat $E$ & Iron-compound $\mathrm{ABC}$ transporter & $\downarrow 6$ & 0.002 & \\
\hline SPR1687 & fatB & Iron-compound $\mathrm{ABC}$ transporter & $\downarrow 10$ & 0.002 & \\
\hline SPR1735 & & $\mathrm{ABC}$ transporter permease protein & 6 & 0.00003 & \\
\hline \multicolumn{6}{|c|}{ Ribonucleotide reductase system } \\
\hline SPR0183 & $n r d D$ & Anaerobic ribonucleoside triphosphate reductase & $\downarrow 4$ & 0.000002 & \\
\hline
\end{tabular}


Table 2. cont.

\begin{tabular}{|c|c|c|c|c|c|}
\hline $\begin{array}{l}\text { Category and } \\
\text { gene ID }\end{array}$ & Gene & Description & Fold change & $P$ value & $\begin{array}{c}\text { qRT-PCR } \\
\text { confirmation }\end{array}$ \\
\hline SPR0185 & $n r d G$ & $\begin{array}{l}\text { Anaerobic ribonucleoside triphosphate reductase } \\
\text { activating enzyme }\end{array}$ & $\downarrow 7$ & 0.00001 & \\
\hline SPR1065 & $n r d E$ & Ribonucleoside-diphosphate reductase & $\downarrow 3$ & 0.000001 & \\
\hline \multicolumn{6}{|l|}{ Competence } \\
\hline SPR1861 & $\operatorname{cglD}$ & Competence protein $\mathrm{CglD}$ & 6 & 0.000003 & \\
\hline SPR2012 & comFC & Competence protein ComF & 12 & 0.007 & $0.4(0.09)$ \\
\hline \multicolumn{6}{|c|}{ Transposons and IS elements } \\
\hline SPR0644 & & Degenerate transposase & 3 & 0.0005 & \\
\hline SP1314 & & IS66 family element, Orf1 & 4 & 0.003 & \\
\hline SPR1349 & & IS630-Spn1 related, Orf2 & 3 & 0.02 & $2.2(0.01)$ \\
\hline SPR1367 & & Transposase & 3 & 0.00005 & $2.1(0.1)$ \\
\hline SPR0184 & & $\begin{array}{l}\text { Acetyltransferase, GCN5-related } N \text {-acetyltransferase } \\
\text { (GNAT) family }\end{array}$ & $\downarrow 7$ & 0.00002 & \\
\hline SPR0290 & gno & Oxidoreductase & $\downarrow 14$ & 0.0005 & \\
\hline SPR0288 & $k d g K$ & Carbohydrate kinase, PfkB family & $\downarrow 15$ & 0.002 & $0.2(0.13)$ \\
\hline SPR0307 & $c l p L$ & ATP-dependent Clp protease & $\downarrow 8$ & 0.0001 & \\
\hline SPR0415 & pfl & Formate acetyltransferase & $\downarrow 4$ & 0.004 & \\
\hline SPR0630 & thiE & Thiamin-phosphate pyrophosphorylase & 4 & 0.0002 & \\
\hline SPR0960 & mutR & Similar to positive transcriptional regulator MutR & 3 & 0.0009 & \\
\hline SPR0918 & asd & Aspartate beta-semialdehyde dehydrogenase & 5 & 0.0001 & \\
\hline SPR1239 & amy & Alpha-amylase precursor & 3 & 0.001 & \\
\hline SP1759 & & Preprotein translocase & 6 & 0.003 & \\
\hline
\end{tabular}

*The microarray results were verified by measuring the expression of selected genes by qRT-PCR. The SD is indicated in parentheses.

in parallel with sp0806F and sp0806R primers. The reactions were performed in triplicate using the following cycling parameters with a MX4000 real-time PCR cycler (Stratagene): 1 cycle of 10 min at $95{ }^{\circ} \mathrm{C}$ followed by 40 cycles of $30 \mathrm{~s}$ at $95{ }^{\circ} \mathrm{C}, 1 \mathrm{~min}$ at $55^{\circ} \mathrm{C}$, and $30 \mathrm{~s}$ at $72{ }^{\circ} \mathrm{C}$. The results were interpreted using the comparative cycle threshold $\left(\mathrm{C}_{\mathrm{T}}\right)$ method (Livak \& Schmittgen, 2001).

Construction of rgg mutants. Two rgg mutant strains were constructed: an insertion mutant in the encapsulated D39 strain background, designated $\operatorname{rgg} M$, and an insertion-deletion mutant in the unencapsulated D39 derivative R6, designated $\Delta r g g$. The mutations were made in two strain backgrounds in order to assess whether the presence of capsule would mask the effects of the rgg mutation on biofilm formation, and the encapsulated mutant was constructed to assess the effect of the mutation on virulence. The list of the primers that were used to construct the mutants is given in Table 1. To construct the $\operatorname{rgg} M$ mutant, the chromosomal region between nucleotides 1921440 and 1923338, containing the rgg (SPD1952) coding sequence, was amplified with the RGGF and RGGR primers. The amplified products were incubated with Himar1 transposase (Lampe et al., 1996) and plasmid pR412, which contains the mariner mini-transposon conferring spectinomycin resistance (Martin et al., 2000). Then, the in vitro-mutagenized DNA was transformed into the pneumococcus using competence-stimulating peptide (Alloing et al., 1996). Transformants were selected for spectinomycin resistance, and insertion of the resistance cassette was confirmed by sequencing, and PCR by combining transposon-specific primers MP127 or MP128 with chromosomal primers RGGF or RGGR, respectively.

To construct the rgg insertion-deletion mutant in R6, the splicing by overlap extension (SOEing) PCR method was used (Horton et al., 1990). The $487 \mathrm{bp}$ fragment containing $31 \mathrm{nt}$ of $\mathrm{rgg}$ and its upstream sequence was amplified with C-SOE-F and D-SOE-R, while a $561 \mathrm{bp}$ fragment containing $8 \mathrm{nt}$ of $\mathrm{rgg}$ and its downstream sequence was amplified using A-SOE-F and B-SOE-R primers. A $1184 \mathrm{bp}$ spectinomycin-resistance gene was amplified from pDL278 with specSOE-F and specSOE-R, which incorporated ends complementary to B-SOE-R and C-SOE-F primers. Finally, equimolar amounts of amplicons containing DNA upstream and downstream of $r g g$, as well as the spectinomycin-resistance cassette, were mixed, and fused by PCR using A-SOE-F and D-SOE-R primers. The amplicons were gelpurified (Qiagen) and transformed into R6 as above, and the mutation was confirmed by PCR and sequencing.

In vivo virulence studies. Female MFI outbred mice, weighing 30 to $35 \mathrm{~g}$, were obtained from Harlan Olac. A standardized inoculum was prepared as described previously (Yesilkaya et al., 2000). Mice were 
lightly anaesthetized with $2.5 \%$ (v/v) fluothane (Zeneca) over oxygen $\left(1.5-21 \mathrm{~min}^{-1}\right)$. A $50 \mu \mathrm{l}$ sample of PBS containing $5 \times 10^{5}$ c.f.u. $S$. pneumoniae was administered into the nostrils. Mice were monitored for clinical signs (progressively starry coat, hunched appearance and lethargy) (Morton, 1985) for 7 days by the researchers and animal housing facility staff who were blinded to the identity of mice, and those that reached the severely lethargic stage were accepted to have reached the end point of the assay and were killed humanely. The time to this point was defined as 'survival time'. Mice that were alive for 7 days after infection were deemed to have survived the infection. To express the disease signs numerically, a score of 2, 4 or 6 was given if the mouse was hunched, had a starry coat, or was lethargic, respectively. Median survival time was analysed by the MannWhitney $U$ test.

To detect bacteria in the blood, approximately $20 \mu \mathrm{l}$ venous blood was obtained from intranasally infected mice at predetermined time points after infection. Viable counts in blood were determined on selective and non-selective media.

\section{RESULTS}

\section{Analysis of microarray data}

The microarray data indicated that the expression of 69 genes was affected in aerobiosis compared with anaerobiosis: 54 genes were upregulated and 15 were downregulated (Table 2). The microarray results were also confirmed by qRT-PCR for selected genes (Table 2).

Expression of sodA (which encodes a manganese cofactored superoxide dismutase) and tpx (which encodes a thiol peroxidase) increased in aerobiosis. This is consistent with their known importance in the oxidative stress response of bacteria (Atack et al., 2008; Yesilkaya et al., 2000). Moreover, upregulation of the gene for the oxygensensitive pyruvate formate lyase $(p f l)$ in anaerobiosis (Neves et al., 2005) indicated that the anaerobic condition was adequately established in this study. The expression of groES, groEL, dnaK, ahpD, SP0313 (glutathione peroxidase) and nox, which are known to take part in the oxidative stress response in other bacteria, was unaltered in aerobiosis, presumably due to use of air in this study instead of $\mathrm{H}_{2} \mathrm{O}_{2}$ or paraquat (Chang et al., 2005, 2006; Mostertz et al., 2004). On the other hand, the transcription of a number of other genes not directly involved in the oxidative stress response displayed an altered pattern of expression. These were hypothetical and conserved hypothetical genes of unknown function and those annotated by homology as genes for genome plasticity, ATP binding cassette $(\mathrm{ABC})$ transporters, ribonucleotide reductase system, Bgl and phosphotransferase system (PTS)-related genes (Lanie et al., 2007; Tettelin et al., 2002).

\section{Involvement of rgg in the oxidative stress response}

The Rgg family of transcriptional regulators is found in Gram-positive bacteria (Chaussee et al., 2003). These include the Rgg and $\mathrm{RggD}$ of Streptococcus gordonii, GadR of Lactococcus lactis, Rgg or RopB of Streptococcus pyogenes and MutR of Streptococcus mutans (Chaussee et al., 2003; Vickerman et al., 2003). In other streptococci, Rggtype regulators have been linked to regulation of adherence, colonization, biofilm formation, carbohydrate and amino acid metabolism, as well as the oxidative stress response (Chaussee et al., 2003, 2004; Pulliainen et al., 2008; Vickerman et al., 2003).

In aerobiosis, SPD1952 (SP2123 and SPR1933 in TIGR4 and R6 genomes, respectively) expression was elevated 11fold compared with in anaerobiosis. This gene was designated $r g g$, since its deduced amino acid sequence shares significant identity with other Rgg-type transcriptional regulators in S. gordonii (46\%), Streptococcus sanguinis (45\%), Streptococcus thermophilus (32\%) and S. pyogenes $(26 \%)$ (Fig. 1). Characteristically, Rgg-type transcriptional regulators contain a helix-turn-helix motif in the N-terminal region (Dmitriev et al., 2008). This motif in SPD1952 shares a sequence identity of 59, 57, 38 and $30 \%$ with the same motif in S. gordonii, S. sanguinis, S. thermophilus and S. pyogenes, respectively (Fig. 1). rgg is present in all sequenced pneumococcal genomes (www.ncbi.nlm.nih.gov), but in TIGR4 SP2123 contains a frameshift in its sequence, possibly leading to an inactive protein. In addition to SPD1952, there are an additional four rgg paralogues, SPD0144, SPD0939, SPD0999 and SPD1518, which exhibit 24, 26, 33 and $23 \%$ homology to SPD1952, respectively (Fig. 2) (Dmitriev et al., 2008). Because of the importance of Rgg in streptococcal biology (Chaussee et al., 2004, 2003; Kreikemeyer et al., 2003; Pulliainen et al., 2008), it was decided to study the role of the annotated $r g g$ in the context of the pneumococcal oxidative stress response.

\section{The rgg mutant exhibits susceptibility to oxidative stress}

As expression of $r g g$ was found to be elevated in aerobiosis, we reasoned that in the absence of Rgg, pneumococci should be more susceptible to oxidative stress. The results showed that the mutant grew as well as the wild-type parental strain under anaerobic conditions in Sicard's defined medium $\left(0.48 \pm 0.05 \mathrm{~h}^{-1}, n=4\right)$. However, under aerobic conditions, the mutant demonstrated a significant growth impairment. While the growth rate of the parental D39 strain was $0.45 \mathrm{~h}^{-1}( \pm 0.03, n=4)$, the growth rate of $r g g M$ was significantly lower: $0.34 \mathrm{~h}^{-1}( \pm 0.03, n=4)$ $(P<0.05)$. In terms of yield, there was no difference between $r g g M$ and D39 (data not shown).

To determine whether Rgg is involved in protection against internally produced superoxide, the pneumococcal strains were exposed for $1 \mathrm{~h}$ to 0.05 or $0.1 \mathrm{mM}$ paraquat, a redoxactive compound that generates intracellular superoxide in the presence of oxygen. Neither concentration affected the survival of D39 compared with unexposed controls (Fig. 3) $(P>0.05)$. However, the percentage survival of $r g g M$ declined to $68 \%( \pm 3, n=3)$ and $41 \%( \pm 4, n=3)$ after exposure to 0.05 and $0.1 \mathrm{mM}$ paraquat, respectively $(P<0.05)$. 
-MEOIGKVFROLRESRNISLROATGGOFSPSMLSRFETGOSELLVEKFLF -MTQLGQVERFFREARHISLSEATGGEFSKSMLSRFENGQSELSAQKLFS -MEHLGQVFRSFREARHI SLSEATGREFSKSMLSRFENGQSELSAQKLFS -MKE E GA IFKKFRKSRGIRLKDVAKAGISTSOLSRFEKGQTDLTITKFMI MEKELGKTLRRLRKGKQVSISFLADEYLSKSQISRFERGESEITCSRLLN

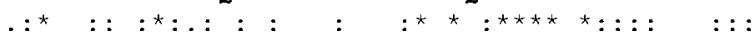

ALENISASVEEILFLARGFQYDTDSELRKEITDVLEPKNIAPLEDLYRRE ALSAIHTETEEFTVAAG IQDHHSHKE LLNQ IQELLQTNQLNLLEKLY-LE ALSAIHTETEEFTVAAG IQDHHSHKEL LSQIQDLLQANQLDLLEELY-LE ILDEINMPIDEFMYAVHDFHRDDLNELLSKIRLFVSTHDI DGLKKLLNSQ LLDKLNITIDEFVSAHSKTHTHF FTLLSQARKCYAEKNVVKLTKLLK--*. : $\quad$ : : $\quad$. . . . . . : : : *

YQKHAESYNKQKH I LNAI I IKSYMKS I DERVDLTAEEGKVLHDYLFSTE I KKKISQKSKESNDWVERL IVKAYLCALKESEKAS PDELDFLHDYLFSVDI KEKITQKSKKASDWVERLIVKAYLCALKESEKASPGELDFLHDYLFSVDI LE--SEPKREKFHH INT I LLKI RLQDLSGESYYTQEDLADLTDYLFSVEY ------DYAHKDYERTMIKAILFSIDSSIAPSQEELTRLTDYLFKVEQ $: \quad::^{\star}: \quad: \quad: \quad: \quad \star \star \star \star \star \ldots:$

WGIYELNLFSVSSPELSVSLFTRYVREMVRKSDF LMEMSGNRNFFHT I LI WGRYELKLFS ICTPVLELDLFSQYTKEI LSRNDFTALEANNRNTLHTTFI WGRYELNLFSVCT PVLSLDLFSQYTKEI LSRKDFAALFANNRNTLHTTEI WGYYELLIFANTL DVLNHET LMV LAKEMSRRSDFYKE I PNNRRMISTMLI WGYYEIILLGNCSREMNYNTLFLLTKEMVASFAYSEQNKTNKMLVTQLSI

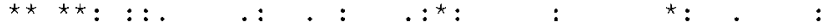

NGFLASIECEKFTNAYYFKRVIEEHFYKENETYFRIVYLWAEGLIDSKOG NGYLLAISQENIAHADYFQQVIERHFYEENETYFRIVYLFAQGELACLKG NGYLLAISQENITQADYFQQVIERHFYEENETCFRIVYLFAQGELICLKG NVY ITCIEREE LI DALYFEKQLNOCF IETE IYERLVEOYAONYYQYKKE NCLI IS IDHSCFEHSRYLINK I DLLLRDELNFYEKTVF LYVHGYYKLKQE * : .*. . : : * . : : : * : : * : ..

RVKEGOKKMEDAVRIFEMLGCNKSAEYYRNTTEC-- -

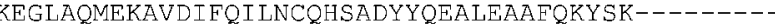
KTEEGLTOMKOA I IFRI LNCQHSADCYQEALDTAFOKYSK--------GNNQSI I EMKKY I GAMKLAGSEHIAKTYEAHLKKLIEENS--------EMS-GEEDMRQALQIFKYLGEDSLYYSYKEHYRQIVLGGKGDEDWSEADI

. . . : : . : *
Fig. 1. Alignment of deduced amino acid sequences of Rgg/MutR family proteins. SPD1952, S. pneumoniae D39 Rgg (accession number YP817340); SGO0500, S. gordonii RggD (accession number 5599480) SSA0615, S. sanguinis RggD (accession number 4806754); STR1572, S. thermophilus MutR (accession number 3166136); and SPY0496, S. pyogenes MutR (accession number 900726). Multiple alignments were performed using the CLUSTAL W program. Asterisks indicate that the aligned residues are identical. Substitutions assumed to be conservative or semi-conservative by CLUSTAL $W$ are indicated by (:) and (.), respectively. The helix-turn-helix motif is indicated in bold type.
The pneumococcus produces $\mathrm{H}_{2} \mathrm{O}_{2}$ under nutrient-rich and aerobic conditions, predominantly by the action of pyruvate oxidase (Pericone et al., 2003). Although the amount of $\mathrm{H}_{2} \mathrm{O}_{2}$ produced by $S$. pneumoniae is lethal for many micro-organisms, pneumococcal growth is not inhibited at high concentrations of endogenously produced $\mathrm{H}_{2} \mathrm{O}_{2}$ (Pericone et al., 2003). However, the factors affecting $\mathrm{H}_{2} \mathrm{O}_{2}$ resistance are not known entirely. Due to the involvement of $\mathrm{Rgg}$ in the oxidative stress response, we tested whether Rgg has any role in protection against $\mathrm{H}_{2} \mathrm{O}_{2}$. It was found that exposure to 20 and $40 \mathrm{mM} \mathrm{H}_{2} \mathrm{O}_{2}$ for $20 \mathrm{~min}$ resulted in a similar level of killing of both $\mathrm{rggM}$ and the parent D39 strain $(P>0.05)$ (Fig. 4). For example, while $92 \%( \pm 4.2, n=3)$ of D39 and $89 \%( \pm 3.4, n=3)$ of rggM survived $20 \mathrm{mM} \mathrm{H}_{2} \mathrm{O}_{2}, 40 \mathrm{mM}$ exposure resulted in a decline in survival to $75 \%( \pm 1.1, n=3)$ and $73 \%( \pm 1.9$, $n=3$ ) for $\operatorname{rggM}$ and wild-type, respectively. This suggested that Rgg does not afford protection against $\mathrm{H}_{2} \mathrm{O}_{2}$.

Analysis of expression of genes downstream of $r g g$ indicated the absence of any polar effect in the mutant. Firstly, the microarray data did not show that the expression of downstream genes was affected by different oxygen concentrations, ruling out their involvement in the oxidative stress response and co-regulation with rgg Secondly, qRT-PCR analysis confirmed that the expression of SPD1951, the gene immediately downstream of $\mathrm{rgg}$, was not significantly different in $\operatorname{rggM}(1.4 \pm 0.2$-fold, $n=3)$ compared with D39, in which the normalized (with gyrB) expression was assumed to be $1(P>0.05)$.

\section{sodA and tpx expression in rggM}

As $\operatorname{sod} A$ and tpx expression was elevated in aerobiosis, the involvement of $\mathrm{Rgg}$ in the regulation of these genes was investigated. qRT-PCR analysis of $\operatorname{sodA}$ and $t p x$ in $r g g M$ showed that while sodA expression was not greatly different (1.6 \pm 0.2 -fold, $n=3$ ) from that in D39, tpx expression was significantly higher in $\operatorname{rgg} M(2.6 \pm 0.2$-fold, $n=3)$ than in D39 $(P<0.05)$, implying that $t p x$ is under the negative control of Rgg. As thiol peroxidase is important for removal of $\mathrm{H}_{2} \mathrm{O}_{2}$, upregulation of tpx in $\mathrm{rggM}$ may partly explain why $\operatorname{rgg} M$ survival was not affected by $\mathrm{H}_{2} \mathrm{O}_{2}$.

\section{Role of Rgg in biofilm formation}

Biofilm-forming ability has an important link to pneumococcal virulence, as has recently been reported (Muñoz- 


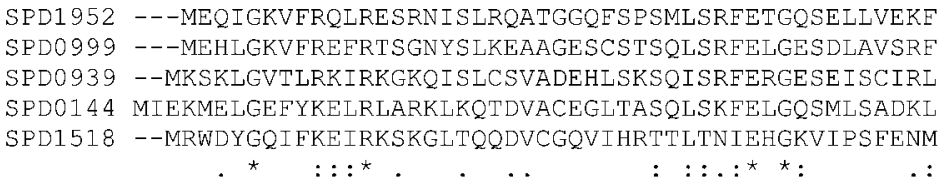

SPD1952 LFAIENISASVEEILELARG--FQYDTDSELRKEITDVLEPKNIAPLEDL SPD0999 EEILDNIHVTIENFMDKARN--FHNHEHVSMMAQI I PLYYSNDIAGFQKL SPD0939 INILDKLHITLDEELILHDEDYTKTESFANLVQYIRKQYSSQSINNIACL SPD0144 ILAIQGINVTEDEFGHKLNN--YQESPHMRIGRKVVNRFAHQDIAALEQL SPD1518 VELLEQIDMSLAEFKYICNEYHPSKRRDIIVESQNPSTFQDTRKMVELTE

$$
\text { . : : : : : : : }
$$

SPD1952 YRREYOKHAHSYNKOKHILNAIIIKSYMKSIDERVDLTAEEGKVLHDYLF SPD0999 QREQLEKSKSSTTPLYFELNWILLQGLICQRDA SYDMKQDDLDKVADYLF SPD0939 LSDT SDYTLNSFEKT-_-_-MVK I LHTMDSNI I PSDEELLHLTDYLF SPDO144 LEEVDQEQMAQTYRR---LNAIVIKDAIHSLNKSYPLAEEDSEFLTTYLY SPD1518 KCQKYLKTHHDVPIQNIYRHTKIVTELRTKGFKNNHVLKDLYEEIWDYLE

$$
:: \quad: \quad: \quad *
$$

SPD1952 STEIWGIYELNLFSVSSPFLSVSLFTRYVREMVRKSDFLMEMSGNRNFFH SPD0999 KTEEWTMYELILFGNLYSFYDVDYVTRIGREVMEREEFYQEISRHKRLVL SPD0939 KIEKWGYYEI ILLGNCVRT INYNSYFLLTKEMLNNYIYSSLNKTNKQIVS SPDO144 AIESWTWFELYLFCNTMPFLSNQDLIELSTSLLEKSKEFKELVHNRTYMK SPD1518 PMDTWYISDLKLLGTILFFEPSENLPLLIDRIMKTIEKYKYFRETKAFLS

$$
: \star \quad:{ }^{*}: \quad:: \text { : }
$$

SPD1952 TILLNGELASIECEKFTNAYYFKRVIEEHFYKENETYER-IVYLWAEGLL SPD0999 ILALNCYQHCLEHSSFYNANYFEAYTEKIIDKGIKLYER-NVEHYLKGFA SPD0939 QLAINCFILSIDKEEFSNCSYLISKIKTLLDNELNFYEQ-TVFLYATGYF SPD0144 QGLLNILSELMERKLFSYIPIFEAELERMLRPYDVFEKVSWQFLKKMSVF SPD1518 SELANLSTVYFQHHLFKECETITLQLLVLAEELK--------IYDILGFS

SPD1952 DSKQGRVKEGQKKMEDAVRI FEMLGCNKSAEYYRNTTEC----SPD0999 LYQKGQCKEGCKQMQEAMH IFDVLGLPEQVAYYQEHYEKFVKSSPD0939 EFKRCQSTSGIEKMKQAIQVEDILGENKLKLHYTDHFNKPVNKK SPD0144 LQTKGSNQKEIERFIQSLQVLENPQLTSLFELREQQYKELID-SPD1518 QVRIGILOHNSDLIDKGITLLRITKEEALVKILEKEINDFSNL-

$$
\text { . : . : : : }
$$

Fig. 2. Alignment of deduced amino acid sequences of SPD1952 paralogues. Accession numbers: Q04MT5 (SPD0144), Q04KN2 (SPD0939), Q04KH4 (SPD0999), and Q04J65 (SPD1518). The alignment was performed and formatted as described in the legend to Fig. 1.
Elías et al., 2008). Moreover, the involvement of Rgg in attachment of other bacteria has been described (Samen et al., 2006); hence, we decided to determine the biofilmforming ability of $\operatorname{rgg}$. Both encapsulated strains, D39 and $\operatorname{rgg}$, formed biofilm equally well, although the number of biofilm-forming bacteria was 100 times less for both strains

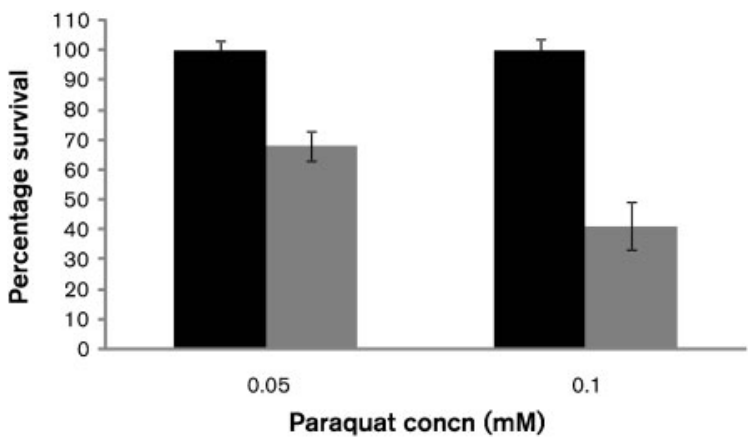

Fig. 3. Effect of paraquat on the survival of pneumococcal strains. Black bars, D39; grey bars, rggM. Error bars indicate SD. relative to R6 (data not shown), presumably due to the effect of capsule which can reduce biofilm formation (Moscoso et al., 2006). However, when capsule was absent, an effect of loss of Rgg was apparent, since the proportion of biofilmforming cells in $\Delta r g g(2.1 \pm 0.3)$ was nearly 50 -fold less than that of the parental strain $(100 \pm 24)(P<0.05)$.

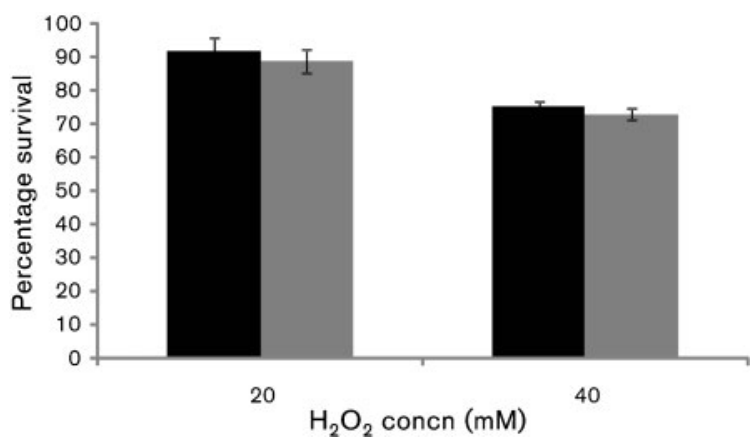

Fig. 4. Susceptibility of pneumococcal strains to $\mathrm{H}_{2} \mathrm{O}_{2}$. Black bars, D39; grey bars, rggM. Error bars indicate SD. 


\section{Virulence test}

In a mouse model of pneumonia it was found that $\mathrm{rggM}$ was less virulent than the D39 parental strain. The median survival time of the $r g g M$-infected cohort $(65 \pm 29 \mathrm{~h})$ was significantly longer than that of the wild-type-infected cohort $(45 \pm 9 \mathrm{~h})(P<0.001)$. Moreover, the onset of disease signs was faster in the wild-type-infected group [disease scores for 24,36 and $48 \mathrm{~h}$ were $2.2( \pm 0.4), 4.4( \pm 0.5)$ and $5.1( \pm 0.4)$, respectively, $n=20$ for each datum point] compared with the rggM-infected cohort [disease scores for 24,36 and $48 \mathrm{~h}$ were $0.7( \pm 0.3), 2.4( \pm 0.4)$ and 2.8 ( \pm 0.5$)$, respectively, $n=20$ for each datum point] $(P<0.05$ at 24 and $36 \mathrm{~h}$, and $P<0.01$ at $48 \mathrm{~h}$ ). While bacteraemia occurred sometime between 4 and $8 \mathrm{~h}$ after intranasal infection in the wild-type-infected group, bacteraemia was at least $4 \mathrm{~h}$ later in the $r g g M$-infected group (Fig. 5). However, once in the blood, there was no difference in the rate of increase in numbers of the two strains, suggesting that mutation of $r g g$ leads to attenuation of the passage of the pneumococcus from the lungs to the blood.

\section{DISCUSSION}

The pneumococcus is exposed to varying levels of oxygen in different host environments; hence, efficient strategies are required to adapt to changes in oxygen concentration. This is needed not only for averting the damaging effects of oxygen radicals but also because variation in oxygen concentration has direct effects on essential traits of pneumococci, such as the regulation of capsular polysaccharide synthesis (Weiser et al., 2001), competence development (Echenique \& Trombe, 2001) and membrane composition (Pesakhov et al., 2007).

We determined the pneumococcal oxidative stress response by exposing the pathogen to a constant flow of environmental oxygen, rather than superoxide-generating agents or hydrogen peroxide. This ensured that an environment similar to that present in the nasopharynx was created, and the induction of a potential shock response was avoided (Mongkolsuk \& Helmann, 2002). In this study, the total number of genes with altered expression was much smaller than in similar studies profiling oxidative stress responses of various other bacterial species (Chang et al., 2005, 2006; Mostertz et al., 2004). While $3.3 \%$ of the pneumococcal genome-coding capacity exhibited altered expression, in other studies this has ranged from 4 to $9 \%$. For example, it was $4 \%$ in Pseudomonas aeruginosa PAO1 (Chang et al., 2005), $7 \%$ in Bacillus subtilis 168 (Mostertz et al., 2004), and 9.1\% in Staphylococcus aureus NCTC8325 (Chang et al., 2006). This could be due to a number of reasons, including genuine interspecies differences in response to oxidative stress, the nature of the stimuli, the microarrays used, and the technical and analytical procedures that were employed.

The results showed that the pneumococcus responds to oxidative stress, firstly by attempting to neutralize ROS and then by reducing the burden of damage. Through the induced expression of genes for enzymes known to deplete ROS, such as superoxide dismutase and thiol peroxidase, the pneumococcus can avert the damaging effect of ROS, while repression of transport of iron into the cell (i.e. by downregulation of $\mathrm{ABC}$ transporters), might prevent the formation of hydroxyl radicals. In addition, the genes essential for the synthesis of genetic material (i.e. ribonucleotide reductase system genes), are downregulated, perhaps protecting the pneumococcal nucleic acids from the potential mutagenic effect of ROS. The genes involved in carbohydrate metabolism were also upregulated in aerobiosis, presumably to meet the increased demand for metabolic energy under stress.

In aerobiosis, the expression of several bgl genes was increased. These genes are involved in carbohydrate utilization, transport and regulation (Amster-Choder \& Wright, 1997; Amster-Choder, 2005). In addition we observed overexpression of PTS genes, notably SP2036 and SP2038 (the same as SPR1847 and SPR1849, respectively). PTS systems have a role in attachment to surfaces in S. mutans and Vibrio cholerae (Abranches et al., 2006; Houot \& Watnick, 2008), but further work is required to establish whether these genes have a similar function in S. pneumoniae. Although upregulation of $b g l$ and PTS system genes was observed in aerobiosis, differential expression may also be due to modification of metabolism for adaptation to aerobic growth conditions.

In bacteria, $\mathrm{ABC}$ transporters are mainly implicated in nutrient uptake and removal of toxins and antibiotics

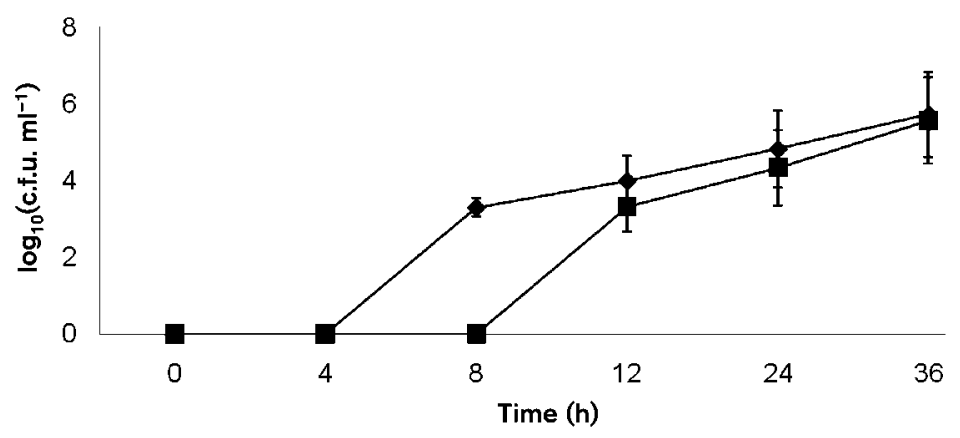

Fig. 5. Numbers of pneumococci in the blood of mice infected intranasally with D39 $(\diamond)$ or $\operatorname{rgg} M(\boldsymbol{\square})$. Each point is the mean $\log _{10}$ (c.f.u. $\mathrm{ml}^{-1}$ ) from 20 mice, except at 4 and $8 \mathrm{~h}$, which are from 10 mice. Error bars indicate SEM. 
(Ulijasz et al., 2004). In aerobiosis, the expression of several $\mathrm{ABC}$ transporter genes decreased, including $\mathrm{fat} D$, fat $C$, fat $E$ and $f a t B$, which form an iron transport operon (Ulijasz et al., 2004). This may be an adaptive response to oxidative stress by reducing levels of intracellular iron, consequently preventing the production of hydroxyl ion via the Fenton reaction (Touati, 2000).

The ribonucleotide reductase systems provide deoxyribonucleoside triphosphates needed for DNA synthesis. Their synthesis is influenced strongly by oxygen in other bacteria (Torrents et al., 2001). In this study we found upregulation of three deoxyribonucleoside triphosphate synthesis genes, $n r d$, in anaerobiosis. $n r d G$ has been found to be upregulated during infection of blood and the central nervous system, where the concentration of oxygen is low (Orihuela et al., 2004), suggesting the importance of the ribonucleotide reductase system in pneumococcal anaerobic growth.

The proportion of hypothetical and conserved hypothetical genes with altered expression in aerobiosis (39\%) outweighed the genomic representation of these classes: 32.7 and $26 \%$ of genome-coding capacity in type 2 and 4 strains, respectively (Lanie et al., 2007; Tettelin et al., 2002). This suggests that some of these genes have a direct role in the oxidative stress response. Indeed, increased expression of some of the hypothetical and conserved hypothetical genes has also been documented in various other experimental models (Martin-Galiano et al., 2005; Orihuela et al., 2004).

The second line of defence against oxidative stress may be mediated by competence and genome plasticity, as we found increased expression of several pneumococcal genes linked to competence and transposition upon exposure to air. Induction of genetic diversity is a way of bacterial adaptation, and can result in enhanced virulence. Oxygen is known to control competence development (Echenique et al., 2000), and induction of competence increases pneumococcal pneumonia (Oggioni et al., 2006). When the pneumococci were subject to aerobiosis, comF [also referred to as comFC (sp2207)], cglD (sp2050) and cglC (sp2051) were upregulated. $c g l C$ and $c g l D$ belong to the $c g l$ locus, which has been described as crucial for the production of competence (Pestova \& Morrison, 1998). On the other hand, $c o m F$ (Rimini et al., 2000) is believed to be important for the late stages of competence (Dagkessamanskaia et al., 2004), as it is in B. subtilis (Ogura et al., 2002).

The Rgg-mediated response was identified as the third mechanism against oxidative stress. We defined a role for pneumococcal $r g g$ in oxidative stress, biofilm formation and virulence. It was found that mutation of $r g g$ renders pneumococci more susceptible to oxidative stress. A similar phenotypic effect has also been reported for an rgg mutant of $S$. pyogenes, which is more sensitive to paraquat (Chaussee et al., 2004). We found that $r g g$ mutation did not alter pneumococcal susceptibility to peroxide; however, mutation of an $r g g$-like gene renders $S$. pyogenes resistant to peroxide (Pulliainen et al., 2008), probably due to upregulation of thiol peroxidase in $\operatorname{rgg} M$, as we determined in this study.

The virulence studies demonstrated that mutation of $r g g$ renders the pneumococcus less virulent than the wild-type strain, and sepsis occurs later in an rggM-infected cohort than in the wild-type-infected group. This could be due to the mutant's susceptibility to oxidative stress and consequently a decreased ability to colonize and invade. However, given that Rgg has a comprehensive effect on various metabolic pathways, such as amino acid and carbohydrate metabolism (Chaussee et al., 2003, 2004; Pulliainen et al., 2008), the reduction in virulence is unlikely to be wholly explained by susceptibility to oxidative stress. Hence, a comprehensive understanding of the role of Rgg in pneumococcal biology requires the study of various regulatory networks affected by this protein, including regulation of the oxidative stress response and genome plasticity. In contrast to the pneumococcus, an $\mathrm{rgg}$ mutant of $S$. pyogenes has been found to be more virulent than its parental strain in a murine intraperitoneal infection model (Chaussee et al., 2003, 2004; Pulliainen et al., 2008). The discrepancy between results is likely to be due to the divergent roles of Rgg in these micro-organisms. Although both the pneumococcal and the S. pyogenes rgg have a helix-turnhelix motif at the $5^{\prime}$ end of the coding sequence that is characteristic of Rgg transcriptional regulators (Dmitriev et al., 2008), the sequence similarity between these two genes is low $(18 \%)$.

Overall, the results of this project indicated that the oxidative response in $S$. pneumoniae is not limited to overexpression of a few genes but it is manifested by the concerted action of complex and integrated pathways.

\section{ACKNOWLEDGEMENTS}

This work was supported by Consejo Nacional de Ciencia y Tecnología (CONACyT), Mexico, and The Wellcome Trust (078763/Z/05/Z). We acknowledge B $\mathrm{GG@S} \mathrm{(the} \mathrm{Bacterial}$ Microarray Group at St George's, University of London) for supply of the microarray and advice, and The Wellcome Trust for funding the multi-collaborative microbial pathogen microarray facility under its Functional Genomics Resources Initiative.

\section{REFERENCES}

Abranches, J., Candella, M. M., Wen, Z. T., Baker, H. V. \& Burne, R. A. (2006). Different roles of EIIAB ${ }^{\mathrm{Man}}$ and $\mathrm{EII}^{\mathrm{Glc}}$ in regulation of energy metabolism, biofilm development, and competence in Streptococcus mutans. J Bacteriol 188, 3748-3756.

Alloing, G., Granadel, C., Morrison, D. A. \& Claverys, J. P. (1996). Competence pheromone, oligopeptide permease, and induction of competence in Streptococcus pneumoniae. Mol Microbiol 21, 471-478.

Amster-Choder, O. (2005). The $b g l$ sensory system: a transmembrane signaling pathway controlling transcriptional antitermination. Curr Opin Microbiol 8, 127-134. 
Amster-Choder, O. \& Wright, A. (1997). BglG, the response regulator of the Escherichia coli bgl operon, is phosphorylated on a histidine residue. J Bacteriol 179, 5621-5624.

Atack, J. M., Harvey, P., Jones, M. A. \& Kelly, D. J. (2008). The Campylobacter jejuni thiol peroxidases Tpx and Bcp both contribute to aerotolerance and peroxide-mediated stress resistance but have distinct substrate specificities. J Bacteriol 190, 5279-5290.

Auzat, I., Chapuy-Regaud, S., Le Bras, G., Dos Santos, D., Ogunniyi, A. D., Le Thomas, I., Garel, J. R., Paton, J. C. \& Trombe, M. C. (1999). The NADH oxidase of Streptococcus pneumoniae: its involvement in competence and virulence. Mol Microbiol 34, 1018-1028.

Cha, M. K., Kim, W. C., Lim, C. J., Kim, K. \& Kim, I. H. (2004). Escherichia coli periplasmic thiol peroxidase acts as lipid hydroperoxide peroxidase and the principal antioxidative function during anaerobic growth. J Biol Chem 279, 8769-8778.

Chang, W., Small, D. A., Toghrol, F. \& Bentley, W. E. (2005). Microarray analysis of Pseudomonas aeruginosa reveals induction of pyocin genes in response to hydrogen peroxide. BMC Genomics 6, 115.

Chang, W., Small, D. A., Toghrol, F. \& Bentley, W. E. (2006). Global transcriptome analysis of Staphylococcus aureus response to hydrogen peroxide. J Bacteriol 188, 1648-1659.

Chaussee, M. S., Somerville, G. A., Reitzer, L. \& Musser, J. M. (2003). Rgg coordinates virulence factor synthesis and metabolism in Streptococcus pyogenes. J Bacteriol 185, 6016-6024.

Chaussee, M. A., Callegari, E. A. \& Chaussee, M. S. (2004). Rgg regulates growth phase-dependent expression of proteins associated with secondary metabolism and stress in Streptococcus pyogenes. J Bacteriol 186, 7091-7099.

Cianciotto, N. P. (2001). Pathogenicity of Legionella pneumophila. Int J Med Microbiol 291, 331-343.

Dagkessamanskaia, A., Moscoso, M., Henard, V., Guiral, S., Overweg, K., Reuter, M., Martin, B., Wells, J. \& Claverys, J. P. (2004). Interconnection of competence, stress and CiaR regulons in Streptococcus pneumoniae: competence triggers stationary phase autolysis of ciaR mutant cells. Mol Microbiol 51, 1071-1086.

Dmitriev, A. V., McDowell, E. J. \& Chaussee, M. S. (2008). Inter- and intraserotypic variation in the Streptococcus pyogenes Rgg regulon. FEMS Microbiol Lett 284, 43-51.

Echenique, J. R. \& Trombe, M. C. (2001). Competence repression under oxygen limitation through the two-component MicAB signaltransducing system in Streptococcus pneumoniae and involvement of the PAS domain of MicB. J Bacteriol 183, 4599-4608.

Echenique, J. R., Chapuy-Regaud, S. \& Trombe, M. C. (2000). Competence regulation by oxygen in Streptococcus pneumoniae: involvement of ciaRH and comCDE. Mol Microbiol 36, 688-696.

Giuliodori, A. M., Gualerzi, C. O., Soto, S., Vila, J. \& Tavio, M. M. (2007). Review on bacterial stress topics. Ann N Y Acad Sci 1113, 95-104.

Green, G. H. \& Diggle, P. J. (2007). On the operational characteristics of the Benjamini and Hochberg false discovery rate procedure. Stat Appl Genet Mol Biol 6, Article27.

Horton, R. M., Cai, Z. L., Ho, S. N. \& Pease, L. R. (1990). Gene splicing by overlap extension: tailor-made genes using the polymerase chain reaction. Biotechniques 8, 528-535.

Hoskins, J., Alborn, W. E., Jr, Arnold, J., Blaszczak, L. C., Burgett, S., DeHoff, B. S., Estrem, S. T., Fritz, L., Fu, D. J. \& other authors (2001). Genome of the bacterium Streptococcus pneumoniae strain R6. J Bacteriol 183, 5709-5717.

Houot, L. \& Watnick, P. I. (2008). A novel role for enzyme I of the Vibrio cholerae phosphoenolpyruvate phosphotransferase system in regulation of growth in a biofilm. J Bacteriol 190, 311-320.
Kadioglu, A., Weiser, J. N., Paton, J. C. \& Andrew, P. W. (2008). The role of Streptococcus pneumoniae virulence factors in host respiratory colonization and disease. Nat Rev Microbiol 6, 288-301.

Kreikemeyer, B., Mclver, K. S. \& Podbielski, A. (2003). Virulence factor regulation and regulatory networks in Streptococcus pyogenes and their impact on pathogen-host interactions. Trends Microbiol 11, 224-232.

Lampe, D. J., Churchill, M. E. \& Robertson, H. M. (1996). A purified mariner transposase is sufficient to mediate transposition in vitro. EMBO J 15, 5470-5479.

Lanie, J. A., Ng, W. L., Kazmierczak, K. M., Andrzejewski, T. M., Davidsen, T. M., Wayne, K. J., Tettelin, H., Glass, J. I. \& Winkler, M. E. (2007). Genome sequence of Avery's virulent serotype 2 strain D39 of Streptococcus pneumoniae and comparison with that of unencapsulated laboratory strain R6. J Bacteriol 189, 38-51.

Livak, K. J. \& Schmittgen, T. D. (2001). Analysis of relative gene expression data using real-time quantitative PCR and the $2^{-\Delta \Delta C T}$ method. Methods 25, 402-408.

Martin, B., Prudhomme, M., Alloing, G., Granadel, C. \& Claverys, J. P. (2000). Cross-regulation of competence pheromone production and export in the early control of transformation in Streptococcus pneumoniae. Mol Microbiol 38, 867-878.

Martin-Galiano, A. J., Overweg, K., Ferrandiz, M. J., Reuter, M., Wells, J. M. \& de la Campa, A. G. (2005). Transcriptional analysis of the acid tolerance response in Streptococcus pneumoniae. Microbiology 151, 3935-3946.

McCluskey, J., Hinds, J., Husain, S., Witney, A. \& Mitchell, T. J. (2004). A two-component system that controls the expression of pneumococcal surface antigen $\mathrm{A}(\mathrm{PsaA})$ and regulates virulence and resistance to oxidative stress in Streptococcus pneumoniae. Mol Microbiol 51, 1661-1675.

McDougald, D., Gong, L., Srinivasan, S., Hild, E., Thompson, L., Takayama, K., Rice, S. A. \& Kjelleberg, S. (2002). Defences against oxidative stress during starvation in bacteria. Antonie Van Leeuwenhoek 81, 3-13.

Mongkolsuk, S. \& Helmann, J. D. (2002). Regulation of inducible peroxide stress responses. Mol Microbiol 45, 9-15.

Morton, D. B. (1985). Pain and laboratory animals. Nature 317, 106.

Moscoso, M., Garcia, E. \& Lopez, R. (2006). Biofilm formation by Streptococcus pneumoniae: role of choline, extracellular DNA, and capsular polysaccharide in microbial accretion. J Bacteriol 188, 77857795.

Mostertz, J., Scharf, C., Hecker, M. \& Homuth, G. (2004). Transcriptome and proteome analysis of Bacillus subtilis gene expression in response to superoxide and peroxide stress. Microbiology 150, 497-512.

Muñoz-Elias, E. J., Marcano, J. \& Camilli, A. (2008). Isolation of Streptococcus pneumoniae biofilm mutants and their characterization during nasopharyngeal colonization. Infect Immun 76, 5049-5061.

Neves, A. R., Pool, W. A., Kok, J., Kuipers, O. P. \& Santos, H. (2005). Overview on sugar metabolism and its control in Lactococcus lactis the input from in vivo NMR. FEMS Microbiol Rev 29, 531-554.

Oggioni, M. R., Trappetti, C., Kadioglu, A., Cassone, M., lannelli, F., Ricci, S., Andrew, P. W. \& Pozzi, G. (2006). Switch from planktonic to sessile life: a major event in pneumococcal pathogenesis. Mol Microbiol 61, 1196-1210.

Ogura, M., Yamaguchi, H., Kobayashi, K., Ogasawara, N., Fujita, Y. \& Tanaka, T. (2002). Whole-genome analysis of genes regulated by the Bacillus subtilis competence transcription factor ComK. J Bacteriol 184, 2344-2351.

Orihuela, C. J., Radin, J. N., Sublett, J. E., Gao, G., Kaushal, D. \& Tuomanen, E. I. (2004). Microarray analysis of pneumococcal gene expression during invasive disease. Infect Immun 72, 5582-5596. 
Paterson, G. K., Blue, C. E. \& Mitchell, T. J. (2006). An operon in Streptococcus pneumoniae containing a putative alkylhydroperoxidase $\mathrm{D}$ homologue contributes to virulence and the response to oxidative stress. Microb Pathog 40, 152-160.

Pericone, C. D., Park, S., Imlay, J. A. \& Weiser, J. N. (2003). Factors contributing to hydrogen peroxide resistance in Streptococcus pneumoniae include pyruvate oxidase $(\mathrm{SpxB})$ and avoidance of the toxic effects of the Fenton reaction. J Bacteriol 185, 6815-6825.

Pesakhov, S., Benisty, R., Sikron, N., Cohen, Z., Gomelsky, P., Khozin-Goldberg, I., Dagan, R. \& Porat, N. (2007). Effect of hydrogen peroxide production and the Fenton reaction on membrane composition of Streptococcus pneumoniae. Biochim Biophys Acta 1768, 590-597.

Pestova, E. V. \& Morrison, D. A. (1998). Isolation and characterization of three Streptococcus pneumoniae transformation-specific loci by use of a lacZ reporter insertion vector. J Bacteriol 180, 2701-2710.

Pulliainen, A. T., Hytonen, J., Haataja, S. \& Finne, J. (2008). Deficiency of the Rgg regulator promotes $\mathrm{H}_{2} \mathrm{O}_{2}$ resistance, AhpCF-mediated $\mathrm{H}_{2} \mathrm{O}_{2}$ decomposition, and virulence in Streptococcus pyogenes. J Bacteriol 190, 3225-3235.

Rimini, R., Jansson, B., Feger, G., Roberts, T. C., de Francesco, M., Gozzi, A., Faggioni, F., Domenici, E., Wallace, D. M. \& other authors (2000). Global analysis of transcription kinetics during competence development in Streptococcus pneumoniae using high density DNA arrays. Mol Microbiol 36, 1279-1292.

Rocha, E. R., Selby, T., Coleman, J. P. \& Smith, C. J. (1996). Oxidative stress response in an anaerobe, Bacteroides fragilis: a role for catalase in protection against hydrogen peroxide. J Bacteriol 178, 6895-6903.

Samen, U. M., Eikmanns, B. J. \& Reinscheid, D. J. (2006). The transcriptional regulator RovS controls the attachment of Streptococcus agalactiae to human epithelial cells and the expression of virulence genes. Infect Immun 74, 5625-5635.

Sicard, A. M. (1964). A new synthetic medium for Diplococcus pneumoniae, and its use for the study of reciprocal transformations at the amiA locus. Genetics 50, 31-44.

Spellerberg, B., Cundell, D. R., Sandros, J., Pearce, B. J., IdanpaanHeikkila, I., Rosenow, C. \& Masure, H. R. (1996). Pyruvate oxidase, as a determinant of virulence in Streptococcus pneumoniae. Mol Microbiol 19, 803-813.

Stewart, G. R., Wernisch, L., Stabler, R., Mangan, J. A., Hinds, J., Laing, K. G., Young, D. B. \& Butcher, P. D. (2002). Dissection of the heat-shock response in Mycobacterium tuberculosis using mutants and microarrays. Microbiology 148, 3129-3138.

Tettelin, H., Masignani, V., Cieslewicz, M. J., Eisen, J. A., Peterson, S., Wessels, M. R., Paulsen, I. T., Nelson, K. E., Margarit, I. \& other authors (2002). Complete genome sequence and comparative genomic analysis of an emerging human pathogen, serotype $\mathrm{V}$ Streptococcus agalactiae. Proc Natl Acad Sci U S A 99, 12391-12396.

Torrents, E., Eliasson, R., Wolpher, H., Graslund, A. \& Reichard, P. (2001). The anaerobic ribonucleotide reductase from Lactococcus lactis. Interactions between the two proteins NrdD and NrdG. J Biol Chem 276, 33488-33494.

Touati, D. (2000). Iron and oxidative stress in bacteria. Arch Biochem Biophys 373, 1-6.

Tseng, H. J., McEwan, A. G., Paton, J. C. \& Jennings, M. P. (2002). Virulence of Streptococcus pneumoniae: PsaA mutants are hypersensitive to oxidative stress. Infect Immun 70, 1635-1639.

Ulijasz, A. T., Andes, D. R., Glasner, J. D. \& Weisblum, B. (2004). Regulation of iron transport in Streptococcus pneumoniae by RitR, an orphan response regulator. J Bacteriol 186, 8123-8136.

Vergauwen, B., Pauwels, F. \& Van Beeumen, J. J. (2003). Glutathione and catalase provide overlapping defenses for protection against respiration-generated hydrogen peroxide in Haemophilus influenzae. J Bacteriol 185, 5555-5562.

Vickerman, M. M., Wang, M. \& Baker, L. J. (2003). An amino acid change near the carboxyl terminus of the Streptococcus gordonii regulatory protein Rgg affects its abilities to bind DNA and influence expression of the glucosyltransferase gene $g t f G$. Microbiology 149, 399-406.

Weiser, J. N., Bae, D., Epino, H., Gordon, S. B., Kapoor, M., Zenewicz, L. A. \& Shchepetov, M. (2001). Changes in availability of oxygen accentuate differences in capsular polysaccharide expression by phenotypic variants and clinical isolates of Streptococcus pneumoniae. Infect Immun 69, 5430-5439.

Yesilkaya, H., Kadioglu, A., Gingles, N., Alexander, J. E., Mitchell, T. J. \& Andrew, P. W. (2000). Role of manganese-containing superoxide dismutase in oxidative stress and virulence of Streptococcus pneumoniae. Infect Immun 68, 2819-2826.

Yesilkaya, H., Forbes, K. J., Shafi, J., Smith, R., Dale, J. W., Rajakumar, K., Barer, M. R. \& Andrew, P. W. (2006). The genetic portrait of an outbreak strain. Tuberculosis (Edinb) 86, 357-362.

Edited by: T. Msadek 